\title{
A Blended Learning Model for Learning Achievement Enhancement of Thai Undergraduate Students
}

\author{
http://dx.doi.org/10.3991/ijet.v11i04.5325 \\ W. Banyen, C. Viriyavejakul and T. Ratanaolarn \\ King Mongkut's Institute of Technology Ladkrabang (KMITL), Bangkok, Thailand
}

\begin{abstract}
Research was undertaken to develop a blended learning model which contained three objectives. They were to 1) study student and teacher input for a blended learning model using a Thai university undergraduate course in information, innovation, and technology in education for the learning management conditions and improvement methods; 2) to research how to effectively improve the blended learning model and instructional media in accordance with the $80 / 80$ criteria and; 3) compare learning achievements and information literacy between student groups using the blended learning method and traditional learning method with information literacy as the covariate. The research was divided into three phases consisting of the development of the conceptual framework, a second phase which studied the blended learning model using both e-learning and face-toface methods with a $60 / 40$ ratio. When applying a technology system to learning management utilizing instructional media, it was determined to be $81.53 / 80.11$. Phase 3 found that blended learning affected learning and information literacy by at least 1 variate which had a different mean score from traditional learning with a statistical significance at the 0.05 level. The findings showed that the Thai university undergraduate students were satisfied with the blended learning model which was due to the change in the learning system as well as being tasked with interesting and challenging computer based lessons outside class. This was later enforced through teacher delivered lesson summaries during formal class time. Students understood the content better, enjoyed the self-directed learning and doing things independently.
\end{abstract}

Index Terms-educational technology; Edmodo; information literacy; self-directed learning; social learning network

\section{INTRODUCTION}

According to e-learning guru Elliott Masie "We are, as a species, blended learners" [1], with some scholars pointing out that people perform better when they have a mix of modalities and methods of learning.

It is commonly said that the present and future world community is and will be a knowledge based society with knowledge and information being the key factors for survival in this new era, which includes politics, culture, the environment, business and economies.

The globalization of business, the shift from production-based to a knowledge-based economy, the growth of information communications technology (ICT), the strive to become learning organizations and the emergence of the needs for knowledge workers have made knowledge management practice a must today across all types and levels of firms [2].

Therefore, one must actively seek knowledge to improve one's self in order to be current with new information and innovation. This leads to the ability to analyze the information which creates even further new knowledge [3]. In an informational society, people suffer 'information overload' due to the massive input and surge of data from resources around us such as e-mail, social media, the Internet, etc.

Once we have received a piece of information, we cannot be certain whether it is factual or not, making it quite difficult to judge as the information has not been screened. Therefore, the overwhelmed users or information seekers must have the essential ability to carry out analytical thinking both in form and content of the information to gain true, credible, trustworthy information that can be employed with quality [4].

The United States National Forum on Information Literacy (NFIL) defines information literacy as "... the ability to know when there is a need for information, to be able to identify, locate, evaluate, and effectively use that information for the issue or problem at hand [5] and in the Alexandria Proclamation of 2005, information literacy was proclaimed that "It empowers people in all walks of life to seek, evaluate, use, and create information effectively to achieve their personal, social, occupational and educational goals. It is a basic human right in a digital world and promotes social inclusion of all nations [6]."

According to a Nielsen survey in 2014, Millennials were stated to be one of the largest population segments in the U.S., totaling about 77 million, on par with the Baby Boomer generation of post WW2. These young consumers are the largest segment of smartphone owners and in the second-quarter 2014, 85\% of Millennials aged 18-24 own devices and $86 \%$ aged 25-34 owned them, an increase from $77 \%$ and $80 \%$, respectively, in second-quarter 2013 [7]. So, just who are these 'millennials'?

Millennials (also known as Generation $Y$ in Thailand) are the social generation. They're the founders of the social media movement-constantly connected to their social circles via online and mobile. They prefer to live in dense, diverse urban villages where social interaction is just outside their front doors [8].

Generation $Y$, born between 1981 and 2000, is the largest generational group and the largest consumer group in Thailand. Generation Y (Gen Y) has also been exposed to various technologies from a very young age and therefore presents the main characteristic of being very tech- 
savvy compared to previous generations, which is especially true when it comes to finding and consuming information [9]. Aside from being tech-savvy, the Thai Generation $\mathrm{Y}$ also presents the specificities of being very social, information-driven, very selective and financially literate.

Given Generation Y's characteristics, this is an excellent sampling group to research and evaluate information literacy skills as it applies to blended learning. Blended learning is a formal education program in which a student learns at least in part through delivery of content and instruction via digital and online media with some element of student control over time, place, path, or pace.

In Thailand, the concepts of the blended learning method is formalized by the National Education Act B.E. 2542 (1999) Class 4, Education Guidelines Section 24 (5). In section 5 it states that learning process should "enable instructors to create the ambiance, environment, instructional media, and facilities for learners to learn and be allround persons, able to benefit from research as part of the learning process. In so doing, both learners and teachers may learn together from different types of teachinglearning media and other sources of knowledge [10]."

Section 24 (paragraph 6), further states that the learning process is to "enable individuals to learn at all times and in all places" and it is therefore paramount that learning management must be investigated, analyzed and improved with blended learning investigated as an alternative.

From the aforementioned background and problems, the researchers found inspiration to study and improve the blended learning model in order to enhance learning achievement and information literacy skills of students of Generation $\mathrm{M} / \mathrm{Y}$ who receive information mainly through digital media.

The research was conducted with undergraduate students from the Faculty of Industrial Education at the King Mongkut's Institute of Technology Ladkrabang (KMITL) who were studying the course 'Information Innovation and Technology in Education' with the stated course objectives being the understanding of educational technology and innovation. Moreover, with the institute's commitment to manage studies in accordance with Thailand's National Education Act [10], the researchers were also eager to improve the blended learning model which can be applied for the benefit of learning management as well as contributing a guideline for future courses.

\section{RESEARCH OBJECTIVES}

The study was concerned with the current learning management conditions and problems as well as the methods for blended learning model improvement of a Thai university course entitled 'Information Innovation and Technology in Education.' Additionally the research was focused on improving the blended learning model and instructional media in accordance with the $80 / 80$ criteria. For purposes of this research and test subjects, 'instructional media; consisted of the following:

1. Edmodo social learning network which is also referred to as a Learning Management Systems (LMS) and Virtual Learning Environment (VLE).

2. Edmodo enables teachers to share content, distribute quizzes, assignments, and manage communication with students, colleagues, and parents.
3. This study used pre-designed and developed infographic forms as well as flash video.

4. Online tutorials in various formats were also used, including exercises of matching, multiple-choice, right - wrong, etc. designed prior to class by professional testing evaluation group.

Comparing learning achievement and information literacy between groups of students with a blended learning method as compared to a traditional learning method was accomplished with information literacy basis as the covariate.

\section{SCOPE OF RESEARCH}

The research process was divided into three phases as follows (Table 1):

Phase 1: This first phase studied current learning management conditions, issues and blended learning model improvement methods for a Thai university course entitled 'Information Innovation and Technology in Education', which were further divided into two steps, which were: 1) study materials and research related to blended learning and 3) the study of current management conditions that benefited blended learning management, the issues and problems and blended learning model improvement methods.

Phase 2: The second phase focused on improving the blended learning model and instructional media in accordance with $80 / 80$ criterion for the student subject course.

Phase 3: Blended learning model experimentation for the Thai university course 'Information Innovation and Technology in Education'.

\section{Materials AND Methods}

The 'Materials and Methods' section has been presented in Table format below for easier visualization and understanding of the 3 separate phases of the research (Table $1)$.

\section{RESUlTS}

Phase 1 research determined that the conceptual model was in line with the literature review. The application of technology on blended learning and learning management consisted of four sections including input, process, output, and monitor and improvement as depicted in the conceptual model below (Fig. 1).

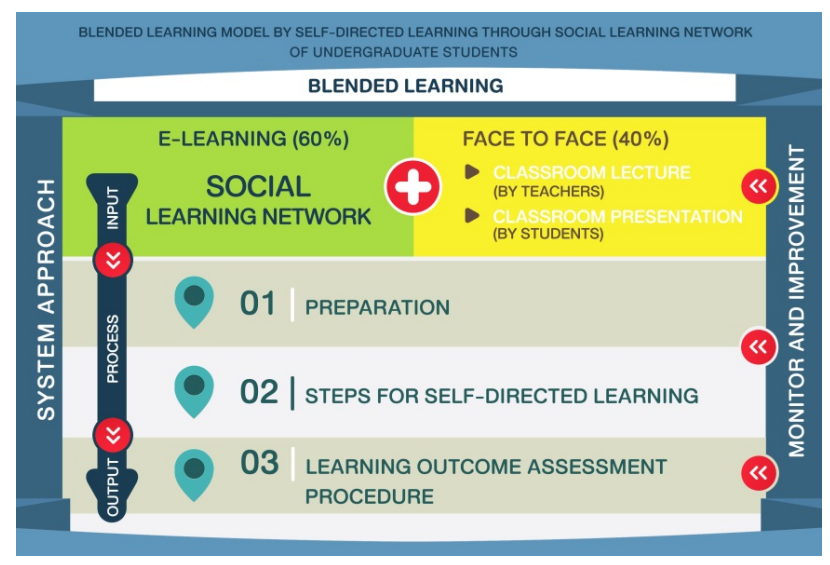

Figure 1. Conceptualized Blended Learning Model (Figure created by the author for this research) 
TABLE I.

MATERIALS AND METHODS

\begin{tabular}{|c|c|c|c|}
\hline Process & Materials & Methods & Information/Informant \\
\hline \multicolumn{4}{|c|}{$\begin{array}{l}\text { Phase 1: Study current learning management conditions, issues and blended learning model } \\
\text { improvement methods of the course 'Information Innovation and Technology in Education' }\end{array}$} \\
\hline $\begin{array}{l}\text { Studied documents } \\
\text { and research } \\
\text { related to blended } \\
\text { learning }\end{array}$ & $\begin{array}{l}\text { 1. Blended learning } \\
\text { element characteristic } \\
\text { record } \\
2 . \text { Thesis characteristic } \\
\text { record }\end{array}$ & $\begin{array}{l}\text { 1. Synthesize blended learning model elements. } \\
\text { 2. Synthesize research on blended learning in Thailand. }\end{array}$ & $\begin{array}{l}\text { 1. Information Source: Thai and } \\
\text { foreign documents related to } \\
\text { blended learning } \\
\text { 2. Source of Information: } 55 \text { Thai } \\
\text { postgraduate theses on blended } \\
\text { learning published from } 2006 \text { - } \\
2013 \text {. }\end{array}$ \\
\hline $\begin{array}{l}\text { Studied learning } \\
\text { management } \\
\text { context for course }\end{array}$ & Interviews & $\begin{array}{l}\text { Studied current learning conditions that benefit blended learning } \\
\text { as well as its problems. Blended learning model improvement } \\
\text { methods were also investigated. } \\
\text { (Please note that the } 3 \text { strong, moderate and weak students were } \\
\text { selected and placed in each category based on test results from } \\
\text { the previous semester's course in educational technology which } \\
\text { contained the same group of student subjects in the experiment.) }\end{array}$ & $\begin{array}{l}\text { Informant Groups: } \\
\text { 1. } 6 \text { course lecturers } \\
2.302013 \text { academic year course } \\
\text { students from } 4 \text { majors consisting } \\
\text { of } 10 \text { strong students, } 10 \text { moderate } \\
\text { students and } 10 \text { weak students } \\
\text { chosen by use of purposive sam- } \\
\text { pling }\end{array}$ \\
\hline \multicolumn{4}{|c|}{ Phase 2: Improved the blended learning model and instructional media in accordance with $80 / 80$ criteria } \\
\hline $\begin{array}{l}\text { Constructed and } \\
\text { examined blended } \\
\text { learning model } \\
\text { prototype }\end{array}$ & Oral questionnaire & $\begin{array}{l}\text { 1. Presented preliminary blended learning model draft to experts } \\
\text { 2. Presented improved blended learning model to experts }\end{array}$ & $\begin{array}{l}\text { Informant Groups: } \\
\text { Three experts on blended learning, } \\
\text { e-Learning design and undergradu- } \\
\text { ate teaching }\end{array}$ \\
\hline $\begin{array}{l}\text { Constructed and } \\
\text { examined social } \\
\text { learning network } \\
\text { for online learning }\end{array}$ & $\begin{array}{l}\text { 1. Media Quality } \\
\text { Assessment of the } \\
\text { social learning net- } \\
\text { work lesson }\end{array}$ & 1. Brought quality assessment to experts' for evaluation & $\begin{array}{l}\text { Informant Groups: } \\
\text { 1. Three experts on blended learn- } \\
\text { ing, e-Learning design and under- } \\
\text { graduate teaching }\end{array}$ \\
\hline $\begin{array}{l}\text { Constructed and } \\
\text { examined social } \\
\text { learning network } \\
\text { for online learning }\end{array}$ & $\begin{array}{l}\text { 2. Content Quality } \\
\text { Assessment of the } \\
\text { social learning net- } \\
\text { work lesson } \\
\text { 3. In-course exercises } \\
\text { and learning achieve- } \\
\text { ment tests }\end{array}$ & $\begin{array}{l}\text { 2. Lecturers evaluated the content of the quality of social learn- } \\
\text { ing network lesson assessments } \\
\text { 3. Utilizing a single classroom and social learning networks, } \\
\text { three rounds of evaluation were undertaken over six weeks. } \\
\text { These included One-to-one evaluation, Small group evaluation } \\
\text { and Large group evaluation conducted according to the learning } \\
\text { management plan }\end{array}$ & $\begin{array}{l}\text { 2. Six professors teaching the } \\
\text { course 'Information Innovation } \\
\text { and Technology in Education.' } \\
\text { Population: } \\
\text { Two classes of } 2014 \text { second se- } \\
\text { mester sophomore students. }\end{array}$ \\
\hline \multicolumn{4}{|c|}{ Phase 3: Blended learning model experimentation } \\
\hline & $\begin{array}{l}\text { 1. Information literacy } \\
\text { basic knowledge test } \\
\text { 2. Learning management } \\
\text { plan } \\
\text { 3. Blended learning } \\
\text { model by self-directed } \\
\text { learning through social } \\
\text { learning network } \\
\text { 4. Edmodo Social learn- } \\
\text { ing network } \\
\text { 5. Learning achievement } \\
\text { test } \\
6 . \text { Information literacy } \\
\text { test }\end{array}$ & $\begin{array}{l}\text { 1. Researchers conducted pre-course information literacy basic } \\
\text { knowledge test } \\
\text { 2. Followed learning activities according to learning management } \\
\text { plan and blended learning model developed by researchers } \\
\text { - } 18 \text { hours over } 6 \text { weeks with } 3 \text { hours per week } \\
\text { - } 11 \text { hours of self-directed learning }(60 \%) \text { and } 7 \text { hours of face-to- } \\
\text { face (classroom lecturing) }(40 \%) \\
\text { 3. Online learning through social learning network using Edmodo } \\
\text { Learning Management System (LMS) } \\
\text { 4. Evaluate learning achievement on cognitive domain in } 5 \text { skills } \\
\text { which are knowledge, comprehension, application, analysis and } \\
\text { evaluation when completing learning duration } \\
\text { 5. Students took information literacy test on information use con- } \\
\text { sisting of } 3 \text { topics which were information resources, information } \\
\text { seeking and access to information after completing a learning } \\
\text { achievement test }\end{array}$ & $\begin{array}{l}\text { Samples: } \\
\text { Two classes of } 2014 \text { second } \\
\text { semester sophomore students. } \\
\text { (Please note in item } 3 \text { the use of } \\
\text { 'Edmodo'. Edmodo was found- } \\
\text { ed in Chicago, Illinois, USA in } \\
2008 \text { by two school district } \\
\text { employees but today is head- } \\
\text { quartered in San Mateo, Cali- } \\
\text { fornia. Currently, it claims to be } \\
\text { the number one K-12 social } \\
\text { learning network in the world } \\
\text { with over } 60 \text { million users.) }\end{array}$ \\
\hline
\end{tabular}

Phase 2 - Step 1 research results found:

\section{1) Blending}

A blending ratio of $60 \%$ e-Learning and $40 \%$ face-toface learning is a suitable blended learning level suggested by the experts.

The Learning Plan Summary consisted of a 6 week course with 3 hours per week for a total of 18 hours with 11 hours $(60 \%)$ of e-Learning (self-directed) while 7 hours $(40 \%)$ was face-to-face (Class lecture) (Table II) .

\section{2) Learning System Management}

The introduction of technology as part of the learning plan consisted of four elements including Input, Process,
Output and Monitoring and Improvement. They are discussed as follows:

\section{A.) Input}

Input for online learning was based on Social Learning Network (Edmodo) principles which are detailed as follows (Fig. 2):

- Social comprised group activities, interaction between students, students and teacher, and teacher and groups of students, as well as reinforcement/motivation. Symbolic rewards were presented to students who achieved perfect scores. 
TABLE II.

60:40 RATIO OF VERTICAL BLENDED LEARNING

\begin{tabular}{ccc}
\hline \multirow{2}{*}{ Wour } & \multicolumn{2}{c}{ Class 3 Hours Duration } \\
\cline { 2 - 3 } & Online Learning & Face to Face Learning \\
\hline 1 & 90 minutes & $\begin{array}{c}90 \text { minutes } \\
\text { Orientation and Registra- } \\
\text { tion included( }\end{array}$ \\
\hline 2 & 2 hours & 1 hour \\
\hline 3 & 2 hours & 1 hour \\
\hline 4 & 2 hours & 1 hour \\
\hline 5 & 2 hours & 1 hour \\
\hline 6 & 90 minutes & $\begin{array}{c}\text { Post-Learning } \\
\text { Assessment included }\end{array}$ \\
\hline Total & $\mathbf{1 1}$ hours & 7 hours \\
\hline
\end{tabular}

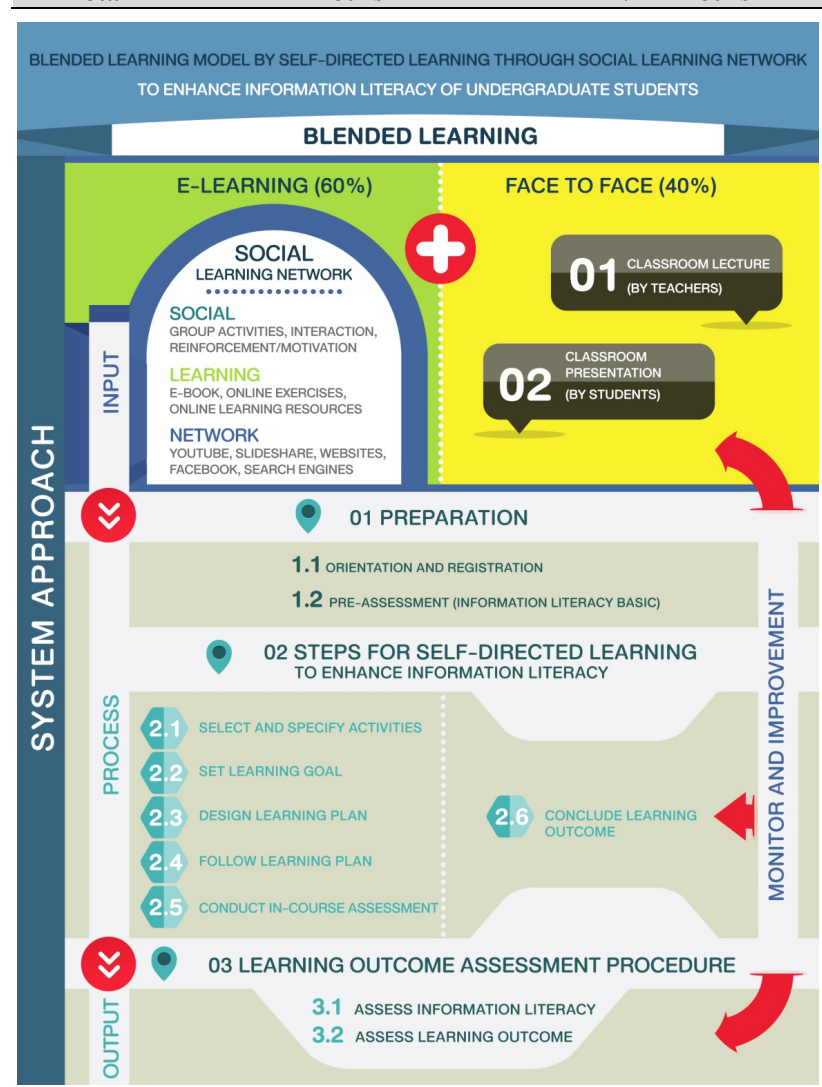

Figure 2. Blended Learning Model by Self-Directed Learning through Social Learning Network to Enhance Information Literacy of Undergraduate Students (Figure created by the author for this research)

- Learning was comprised of online learning management supporting tools namely e-books, online exercises and online learning resources. Lecturers provided guidance and knowledge related to credible and related content and sources.

- Network comprised of connections to online learning resources which were associated with course content and activities such as YouTube, websites, search engines, Slideshare and Facebook.

Input for face-to-face learning used 2 learning methods including 1) classroom lecture (by teachers) and 2) classroom presentations and $\mathrm{Q} / \mathrm{A}$ (by students).

\section{B.) Process}

Process consisted of three steps outlined as follows: - Preparation
Orientation and Registration for students involved practicing how to effectively use the Social Learning Network (Edmodo) while introducing how a student's progress and self-learning procedures are evaluated. Specifically:

Orientation - This entailed the lecturer clarifying to students the details of the course and the understanding of the knowledge tools to be used. It also involved the explanation of the self-directed learning steps, which were model, process, learning tools and assessment.

Registration - All students were required to register through the Social Learning Network (Edmodo) for tracking and lesson practice.

Pre-Assessment - Pre-assessment of information literacy was compulsory as knowing the basic knowledge may be a factor affecting information literacy achievement.

- Weekly Activity Steps

Weekly activity steps to enhance information literacy by use of self-directed learning were as follows:

Select and Specify Activities - Students were given the freedom to specify and select subject matter for the course for the purpose of increasing their interest in it.

Set Learning Goal - In this step, students set their individual learning goals and researched information related to these subjects so that they could respond to questions or activities relating to the course content that teachers assigned.

Design Learning Plan - Students were allowed to select learning methods or processes individually.

Follow Learning Plan - Students used the Social Learning Network (Edmodo) to study content, online learning resources, and to conduct activities to enhance their learning and information literacy. This included three attributes; sources of information, searching for information and a critical approach to information.

Conduct In-Course Assessment - Students did exercises on subject matter.

Conclude Learning Outcome - Students and lecturers concluded their learning outcome. Students also worked in and participated in classroom presentations.

\section{- Learning Outcome}

An assessment procedure was conducted after all course content had been completed with the students being evaluated in two sections. First, students took a learning achievement assessment to reveal their respective learning achievement which was compared to the assessment standard. Second, students took an information literacy assessment to reveal their learning achievement as it compared to a pre-course information literacy basic knowledge assessment.

\section{C.) Output}

Output - This consisted of Learning Achievement and Information Literacy, which are detailed as follows:

- Learning Achievement relates to post-course test scoring of students.

- Information Literacy relates to post-course information literacy test scoring which utilized the Media and Information Literacy Competencies Catalogue prepared by The Modern Poland Foundation [11]. Media literacy represents the competence to access the media, to understand and to have a critical approach towards different aspects of media contents and create communications in a 
variety of contexts [12]. The concepts of media literacy and information literacy become increasingly linked as content via the Internet and mobile platforms become more accessible [13].

\section{D.) Monitor and Impovement}

Monitor and improvement - As with any area of learning it was necessary to evaluate student's progress and any problems they might be encountering. This hopefully allows the lecturers to adjust/change/improve the classroom content for the following weeks.

Phase 2 Step 2 found:

Set Learning Goal - In this step, students set their individual learning goals and researched information related to these subjects so that they could respond to questions or activities relating to the course content that teachers assigned.

After the prototype instructional media had been produced, four media performance criteria were evaluates as follows:

1) Students who used instructional media without any score criterion were conducted with a first round of oneto-one evaluation consisting of 3 students, mixed of strong, moderate and weak students.

Information gained from the experiment was divided into four categories that needed improvement which were; colors, illustrations, content presentations and exercise formats.

2) Students who used instructional media without any score criterion were conducted with a second round of small group evaluation consisting of 9 students who were not from the first round, mixed of 3 strong, 3 moderate and 3 weak students. Information gained from the experiment was divided into two categories which were; advantages of media and media capability for additional improvement.

3) The researchers introduced instructional media to content and media producing experts for assessment. The assessment found that the content had a mean equal to 4.64 which is considered good quality media. For media production, it equals 4.47 which are also considered as good quality media. Expert's assessment scores were over 3.50 which are considered as effective media.

4) The researchers conducted a Large Group Evaluation experiment with 30 students at the end of the 6 week test period to evaluate the improved media. The conclusion was that instructional media efficiency equals to $81.53 / 80.11$ which is almost equal to the $80 / 80$ criteria showing that the instructional media was effective.

Phase 3 - Comparison of learning achievement and information literacy between the blended learning group and the traditional learning group research found:

The researchers divided the data analysis into two sections (Table III). One was the analysis results of the basic knowledge of information literacy mean score compared to the blended learning group and traditional learning group. Also there was a multivariate analysis of variance result of learning achievement and information literacy between the blended learning group and the traditional learning group.

Table III results show the researchers assumption examination of independent t-test on homogeneity of vari-
TABLE III.

ASSUMPTION IN BASIC MEAN SCORE OF INFORMATION LITERACY BETWEEN BLENDED LEARNING GROUP AND TRADITIONAL LEARNING GROUP ('TRADITIONAL' IS DEFINED AS A 'BRICKS AND MORTAR' CLASSROOM, CONTAINING CHAIRS, WHITEBOARD, SET CLASS TIMES, CLASSROOM LECTURER, ETC.)

\begin{tabular}{|c|c|c|c|c|c|c|c|c|}
\hline & \multirow{2}{*}{$\mathbf{N}$} & \multirow{2}{*}{$\bar{x}$} & \multirow{2}{*}{ SD } & \multicolumn{2}{|c|}{ Levene's Test } & \multirow{2}{*}{$\mathbf{t}$} & \multirow{2}{*}{ df } & \multirow{2}{*}{ Sig. } \\
\hline & & & & $\mathbf{F}$ & Sig. & & & \\
\hline $\begin{array}{c}\text { Blended } \\
\text { Learning } \\
\text { Group }\end{array}$ & 30 & 16.9333 & 3.3107 & \multirow{2}{*}{.556} & \multirow{2}{*}{.459} & .874 & 58 & .386 \\
\hline $\begin{array}{c}\text { Traditional } \\
\text { Learning } \\
\text { Group }\end{array}$ & 30 & 16.1333 & 3.7667 & & & .874 & 57.060 & .386 \\
\hline
\end{tabular}

ance of each population nu usw of the 'Levene Test fr Equality of Variances' [14] and found no difference with the statistical significance at the 0.05 level, meaning that both groups achieved homogeneity of variance, so therefore the researchers applied Pooled Variance t-test statistics [15].

Data analysis found that the blended learning group had an information literacy basic knowledge mean score equal to 16.9333 and a standard deviation equal to 3.31073 , whereas the traditional learning group had an information literacy basic knowledge mean score equal to 16.1333 and a standard deviation score equal to 3.76676

Comparison of the information literacy basic knowledge mean scores between the blended learning group and the traditional learning group found that the information literacy basic knowledge mean scores of the blended learning group and the traditional learning group had no difference with a statistical significance at the 0.05 level, signifying that both student groups had almost even competence. Therefore, information literacy basic knowledge scores were not analyzed as covariate.

Table IV show the assumption examination on multivariate analysis of variance by applying Box's M Test [16] to examine the matrix equality of variance and covariance in order to study the equality of variance and covariance between the blended learning group and the traditional learning group. The conclusion was that the variance and covariance matrix are equal (Table 4).

Bartlett's test [17] was used to examine the dependent variable relationship of learning achievement and information literacy and found that there was a relationship between learning achievement and information literacy (Table 4).

Wilks' Lambda [18] found that blended learning had an effect on learning achievement and information literacy with a mean score of least 1 variable, dissimilar to traditional learning which had a statistical significance at the 0.05 level. The researchers therefore further analyzed variable differences.

Learning achievement analysis found that the blended learning group had a mean score equal to 21.6333 with a standard deviation equal to 3.2107 , whereas the traditional learning group had a mean score equal to 18.9333 with a standard deviation equal to 3.8590 . Comparing learning achievement scores between the blended learning group and the traditional learning group found that the blended learning group had a higher mean score than the traditional learning group with a statistical significance at the 0.05 level. 
TABLE IV.

ASSUMPTION IN MULTIVARIATE ANALYSIS OF VARIANCE RESUlt

\begin{tabular}{ccccc}
\hline $\begin{array}{c}\text { Independent } \\
\text { Variable }\end{array}$ & Statistic & Value & F & Sig. \\
\hline \multirow{3}{*}{$\begin{array}{c}\text { Learning } \\
\text { Style }\end{array}$} & Pillai's Trace & .140 & 4.626 & .014 \\
\cline { 2 - 5 } & Wilks' Lambda & .860 & 4.626 & .014 \\
\cline { 2 - 5 } & Hotelling's Trace & .162 & 4.626 & .014 \\
\cline { 2 - 5 } & Roy's Largest Root & .162 & 4.626 & .014 \\
\hline Box's M test 12.448, F 3.994 - Bartlett's Test $17.806, .000$ \\
\hline
\end{tabular}

Information literacy analysis found that the blended learning group had a mean score equal to 21.3000 with a standard deviation equal to 2.3657 , while the traditional learning group had a mean score equal to 20.6333 with a standard deviation equal to 4.0384 .

Table V shows the comparison of learning achievement and information literacy results between the blended learning group and the traditional learning group by separately analyzing learning achievement and information literacy. Data analysis result is as follows:

Comparing information literacy scores between the blended learning group and the traditional learning group found that the blended learning group and the traditional learning group had no difference in mean scores with a statistical significance at the 0.05 level.

TABLE V.

ANALYSIS RESULTS OF LEARNING ACHIEVEMENT AND INFORMATION LITERACY COMPARISON BETWEEN BLENDED LEARNING GROUP AND TRADITIONAL LEARNING GROUP

\begin{tabular}{|c|c|c|c|c|c|c|c|c|}
\hline \multirow{3}{*}{$\begin{array}{l}\text { Dependent } \\
\text { Variable }\end{array}$} & \multicolumn{4}{|c|}{$\begin{array}{c}\text { Independent Variable } \\
\text { Learning Style }\end{array}$} & \multirow{3}{*}{\multicolumn{2}{|c|}{$\begin{array}{l}\text { Levene's } \\
\text { Test }\end{array}$}} & \multirow{3}{*}{ t } & \multirow{3}{*}{ Sig. } \\
\hline & \multirow{2}{*}{\multicolumn{2}{|c|}{$\begin{array}{l}\text { Blended Learning } \\
\text { Group }(\mathbf{N}=\mathbf{3 0})\end{array}$}} & \multirow{2}{*}{\multicolumn{2}{|c|}{$\begin{array}{l}\text { Regular Learning } \\
\text { Group (N=30) }\end{array}$}} & & & & \\
\hline & & & & & & & & \\
\hline $\begin{array}{c}\text { Learning } \\
\text { Achievement }\end{array}$ & 21.6333 & 3.2107 & 18.9333 & 3.8590 & .553 & .460 & 8.678 & .005 \\
\hline $\begin{array}{l}\text { Information } \\
\text { Literacy }\end{array}$ & 21.3000 & 2.3657 & 20.6333 & 4.0384 & 4.223 & .05 & .609 & .438 \\
\hline
\end{tabular}

\section{Learning Method Comparison}

- Learning Achievement: blended learning group had higher score than traditional learning group

- Information Literacy: blended learning group and traditional learning group had no difference

\section{DISCUSSION}

The first phase of the research was to study current conditions, problems and issues of learning management and blended learning model improvement methods. This was subsequently divided into two sections.

Section 1 - Blended learning studies concerning its use in technology fields have seen the greater proportion of research in recent years. This is most likely due to the need to understand teaching and learning methods that involve technology which support learning management. Thus, most readily available study samples were secondary schools and undergraduate programs.

From the research synthesis, e-Learning, computer aided instruction (CAI), and social media lessons were applied most in blending. Learning Management System (LMS) use such as Edmodo in blended learning and its underlying use principles is of yet not defined.

Social learning network principles however were determined to be a new and interesting which can be applied to blended learning methods for greater effectiveness.
This is consistent with Johnson, McHugo \& Hall [19] which stated that blended learning is most suitable for Millennial Generation learners (18-24 years old), and who are familiar with the use of technology.

Borg, O'Hara \& Hutter [20] stated that Edmodo was created to bring education into a 21 st century environment. Today, according to Edmodo's home page, it is the number one K-12 'social learning network' in the world, dedicated to connecting all learners with the people and resources they need to reach their full potential.

Section 2 - The next section of the study was to study teachers' and students' current learning management conditions that benefit blended learning management and blended learning model improvement methods. Researchers found that answers were in the same direction as the research inquiry. Specific details are as follows:

The research was conducted over 5 subjects: learning management, self-study encouragement, environment for cooperative learning, assessment and evaluation of the learners and the usage of various media, materials and equipment to support the learning. This was conducted according to the theory on the factors incorporating the blended learning by Carman [21].

Learning management - The present learning and teaching employed for the course was mainly that of the traditional lecture. This is the method in which the lecturers came and met the students. It is noted that for blended learning, the presence of the live event is also a factor.

Self-study encouragement - Each of the lecturers employed different techniques to encourage student selfstudy. Techniques such as project base learning and report preparation helped the students to conduct their own information search. This also included research on eLearning from related websites.

Environment - For cooperative learning, the lecturers communicated via many channels such as electronic mail, social media, the LINE application and websites which allowed the learners and the lecturers to communicate and share learning.

Assessment and the evaluation of the learners - This was accomplished according to the institute's regulations which are comprised of midterm exams, the final exam, and class participation and student activity.

Media, materials and equipment usage - In support of the learning process, the lecturers employed similar media, materials and equipment including printed media, multimedia, visual media, database and website articles, IT equipment, diagrams and models. Other materials included the actual items, CAI and AR (Augmented Reality) media.

There were 3 items identified as current problems by the lecturers/students regarding teaching/learning management. They are summarized as follows:

Learners - The lecturers' felt they had made their best effort in adjusting their teaching methods, their content presentations and their teaching/learning management in order to make the class more interesting and suitable as the learners from different groups/programs had different learning abilities.

Learners' on the other hand seemed to agree with that of the lecturers in that they also wanted the lecturers to adjust their presentation methods, their lectures and their 
learning formats. The on-line format was suggested in this regard.

1. Class room - Current classrooms were not suitable for the course which included seat arrangements and the lack of equipment.

2. Lecturers - The students felt concerned that the lecturers may not be able to lead the class due to other appointments and commitments.

Improvements for course blended learning identified 2 items listed below:

1. Both the lecturers and the students share the same opinion that blended learning development is very interesting and has the potential to solve problems experienced by course students. The ability to alter course content and teaching methods by the lecturers in order to match the interests of the students was stated as a positive attribute of the blended learning concept

2. The lecturers also felt that e-Learning material preparation and the use of technology increased the efficiency in teaching/learning process. From the students' side, they suggested that more visual content with color should be used with less text. The video contents and the exercises should be included and the ability to communicate between the students and the lecturers should be utilized.

The next objective was to improve blended learning model and instructional media in accordance with $80 / 80$ criteria by drafting the preliminary blended learning model according to the conceptual framework. After extensive research to discover the best tool to implement the study's 'social learning network', Edmodo was found to be suitable due to the following characteristics:

- Social - Edmodo could create group activities as well as help facilitate interaction between student to student, student to teacher and teacher to students through comments, group assignments, content, emotional expression through Emoticon. Achievements are recognized through 'Award Badges' which boost and reinforces motivation.

- Learning - Edmodo was able to store and share online content as well as teacher generated online learning resources and exercises that students were able to access their once they had finished.

- Network - Edmodo can increase links to other online learning resources, such as YouTube, websites, search engines, Slideshare, Facebook, etc.

Self-paced, asynchronous learning events add significant value to the blended learning equation. In order to get maximum value-real business results-from a self-paced learning offering, it must be based on effective implementation of instructional design principles (Carman, 2005 [21].

Knowles puts forward three immediate reasons for selfdirected learning. First he argues that there is convincing evidence that people who take the initiative in learning (proactive learners) learn more things, and learn better, than do people who sit at the feet of teachers passively waiting to be taught (reactive learners). 'They enter into learning more purposefully and with greater motivation. They also tend to retain and make use of what they learn better and longer than do the reactive learners.' [22].
Knowles [22] also states that in the process of developing learning activities to enhance information literacy, educators should analyze learning needs, establish learning goals, set learning plans, seek technology resources and assess the results.

The last objective was to compare learning achievement and information literacy between the groups of students using the blended learning method and the traditional learning method. Research results found that the learning achievement mean score of the blended learning group was higher than the score for the traditional learning group. Information literacy mean scores however had no differences between the two groups.

Students were satisfied with the blended learning model experiment and its changes from the old-fashioned learning model which solely included classroom lectures. This coincided with a report from Echo360 [23] which concluded $63 \%$ students had shown their satisfaction on a blended learning environment. Students preferred blended learning methods to exclusively face-to-face learning or online learning.

Chew's [24] research results also show that blended learning involves the combination of two fields of concern: technology and education; or two groups of people: technologists and educationists.

This study aimed to explore, analyze and compare the blended learning experience in higher education with the research reflected in 3 questions; (1) What are the current blended learning experiences in the selected higher educational institutions? (2) How such experience varies in different disciplines? (3) What are the reflections on the comparative experiences in (1) and (2)?

\section{CONCLUSION}

The experiment on a blended learning model utilizing social learning network principles and tools found that students were satisfied with the model and principles. In conclusion, students were satisfied with the blended learning model as it was a change in the traditional learning system which allowed students to study interesting and attractive lessons on computers before class, followed by in-class teacher delivered lesson summaries afterwards.

Students were encouraged to obtain more understanding of content in order to execute classroom activities and exercises. The outcome was that the students understood the content much better and enjoyed self-directed learning and individuated information research.

Time blending activities focused on interactions among students was a positive process as students were allowed to make decisions, select topics, analyze and discuss class work. They were also able to collaborate with fellow classmates who might not have clearly understood the assigned material.

Students commented on Edmodo that it was easy to use, uncomplicated, allowed the orderly submission of assignments, separated assignment sections and lesson sections clearly and was able to boost learning in both lesson content and information literacy.

Research results from the two test groups of blended learners and traditional learners found that blended learning affected learning and information literacy by at least 1 variate, which had a different mean score from traditional learning with a statistical significance at the 0.05 level. 


\section{REFERENCES}

[1] A. Rossett, Best Practices, Strategies, and Case Studies for an Emerging Field, New York: McGraw-Hill. 2002.

[2] S.C. Chong, Implementation of knowledge management among Malaysian ICT companies: An empirical study of success factors and organisational performance. Unpublished academic dissertation. Multimedia University, Malaysia. 2005. [Online]. Available: https://tinyurl.com/zsrvkav [Accessed: 1 - Dec - 2015].

[3] R. Baskerville and A. Dulipovici, The theoretical foundations of knowledge management, Knowledge Management Research \& Practice (2006) 4, 83-105. doi:10.1057/palgrave.kmrp.8500090. [Online]. Available: https://tinyurl.com/hlc82qf [Accessed: 1 Dec - 2015]. http://dx.doi.org/10.1057/palgrave.kmrp.8500090

[4] U. Gasser, S. Cortesi, M. Malik and A. Lee, Youth and Digital Media: From Credibility to Information Quality. [Online]. Available: https://tinyurl.com/gokbthg [Accessed: 1 - Dec - 2015].

[5] What is the NFIL? United States National Forum on Information Literacy (NFIL) [Online]. Available: https://tinyurl.com/gwos6k7 [Accessed: 1 - Dec - 2015].

[6] S. D. Garner, High-Level Colloquium on Information Literacy and Lifelong Learning Bibliotheca Alexandrina, Alexandria, Egypt November 6-9, $2005 . \quad$ [Online]. Available: https://tinyurl.com/z9kh6dz [Accessed: 1 - Dec - 2015].

[7] Mobile Millennials: Over $85 \%$ of Generation Y Owns Smartphones. Nielsen. 09-05-2014 [Online]. Available: https://tinyurl.com/q39v56q [Accessed: 1 - Dec - 2015].

[8] Millennials: Breaking the Myths - 01-27-2014. [Online]. Available: https://tinyurl.com/lu65dc3 [Accessed: 1 - Dec - 2015].

[9] Siam Commercial Bank Economic Intelligence Center, Marketing to Generation Y in Thailand. 1 May 2015. [Online]. Available: https://tinyurl.com/o9xfor2 [Accessed: 30 - Nov- 2015].

[10] National Education Act B.E. 2542 (1999). [Online]. Available: https://tinyurl.com/z9eftsk [Accessed: 30 - Nov- 2015].

[11] Media and Information Literacy for Knowledge Societies, International Conference on Media and Information Literacy for Knowledge Societies (Moscow, Russian Federation, 24-28 June, 2012, Moscow: Interregional Library Cooperation Centre, 2013. 432 p. [Online]. Available: https://tinyurl.com/ho4u8sm [Accessed: 30 - Nov- 2015].

[12] T. Jereissa, J. Cappi, \& F. Senne, Children and ICTs in Brazil: An Approach to Media Literacy, Media and Information Literacy for Knowledge Societies, 2012. pp. 307-315. [Online]. Available: https://tinyurl.com/ho4u8sm [Accessed: 30 - Nov- 2015].
[13] UNESCO, Towards Media and Information Literacy Indicators. 2011. [Online]. Available: https://tinyurl.com/jhbqzfr [Accessed: 30 - Nov- 2015].

[14] Levene Test for Equality of Variances, Engineering Statistics Handbook. [Online]. Available: https://tinyurl.com/2h6fzg [Accessed: 2 - Dec - 2015].

[15] P.R. Killeen, An alternative to null-hypothesis significance tests. Psychol Sci 16 (5): May, 2005. pp. 345-53. doi:10.1111/j.09567976.2005.01538.x. [Online].Available: ttps://tinyurl.com/zdgdkot [Accessed: 2 - Dec - 2015]. http://dx.doi.org/10.1111/j.09567976.2005.01538.x

[16] Box's M Test. IBM Knowledge Center. [Online]. Available: https://tinyurl.com/h63q3ht [Accessed: 2 - Dec - 2015].

[17] Bartlett's Test, Engineering Statistics Handbook. [Online]. Available: https://tinyurl.com/2dlpyc [Accessed: 2 - Dec - 2015].

[18] Wilks' Lambda, Defning and assessing competence: issues and debate. Journal of Clinical Nursing, 9, 2000. pp. 369-381. [Online]. Available: https://tinyurl.com/zml7dnt [Accessed: 2 Dec - 2015].

[19] K. Johnson, C. McHugo, C., and T. Hall, Analysing the efficacy of blended learning using technology enhanced learning (TEL) and m-Learning delivery technologies. 2006. [Online]. Available: https://tinyurl.com/jzn9fju [Accessed: 1 - Dec - 2015].

[20] N. Borg, J. O'Hara, and C. Hutter, C., About Edmodo-Our story. 2008. [Online]. Available: https://tinyurl.com/odekr8s [Accessed: 1 - Dec - 2015].

[21] M.J. Carman, Blended Learning Design: Five Key Ingredients. 2005. [Online]. Available: https://tinyurl.com/humkv67 [Accessed: 1 - Dec - 2015].

[22] M.S. Knowles, Self-Directed Learning. 1975. [Online]. Available: https://tinyurl.com/j9epo37 [Accessed: 1 - Dec - 2015].

[23] Echo360. Blended Learning Technology: Connecting with the Online-All-the-Time Student. 2012. pp. 8. [Online]. Available: https://tinyurl.com/j7sjts3 [Accessed: 1 - Dec - 2015].

[24] E. Chew, A Blended Learning Model in Higher Education: A Comparative Study of Blended Learning in UK and Malaysia (Doctoral dissertation), the University of Glamorgan, Malaysia. 2009.

\section{AUTHORS}

W. Banyen, C. Viriyavejakul and T. Ratanaolarn are with King Mongkut's Institute of Technology Ladkrabang (KMITL), Bangkok, Thailand.

Submitted 02 December 2015. Published as resubmitted by the authors 13 february 2016. 